\title{
The Urgency of State Defense in Enacting Leadership
}

\author{
Iswahyuni; Subakdi; Angela Efianda \\ Dosen UPN Veteran, Jakarta, Indonesia \\ https://ijmmu.com/index.php/ijmmu/article/view/3014
}

\begin{abstract}
UPN "Veteran" Jakarta is a university that has fulfilled the requirements on consideration of becoming a state-owned university as proposed by the Ministry of Culture and Education. Out of three considerations for the conversion of private university to a state university, the UPN "Veteran" Jakarta has fulfilled two considerations. Which is that the UPN "Veteran" Jakarta has something novel that can't be offered by any other universities as the university based on state defense ideas. State defense is an effort by every citizen in defending its nation, where it's realized in form of patriotism and willingness to sacrifice. Leadership in general terms are the ability or the capability to influence others in order to achieve a certain goal. It is a trait innate in every leader which constituted of: personality, capability, and willingness. Leadership is a sequence of activities done by the leader that can't be separated from its position, style, and the attitude of said leader. As well as their interaction with the followers and the situation related to. Based on the stated background our team will resume the research by exploring further how urgent it is the value of state defense in enacting the leadership role.
\end{abstract}

Key words: Urgency; State Defense; Leadership; Patriotism

\section{Introduction}

\subsection{Background}

Urgency implies something of importance or something that needs to be done immediately. Value serves as the tool to gauge whether a certain means and ends are socially preferable compared to other certain differing means and ends. Value contains the element or measure that brought with it the ideas of an individual concerning the right, the good, and preferences. State defense is the action and the attitude of a citizen of the state that is based on devotion towards the states, belief in Pancasila as the state's ideology, willingness to sacrifice in face of any threats, hurdles, and disruptions.

UPN "Veteran" Jakarta as the college based on the "Bela Negara (State Defense)" idea has the active roles in enriching its human resources by contributing to teaching and socializing the idea of state defense. This is done in order to ensure that every member of its faculty possess a strong character related to state defense along with a strong will against any possible challenges that may come.

Every element of the higher education will strive to answer the challenges through the process of learning that is based on state defense, a challenge especially for the lecturers in charge of subject directly 
related to the idea of state defense. That is why there is the need of effective communicating ability in order to convey its learning subjects, Hence, each lecturers needs to be an efficient communicator dan able to encourage dialogues in the process of learning.

This method of learning through dialogues will be very effective in teaching the students to understand the subjects, ensuring an active and interactive as well as a proper form of dialogues. A nationalistic character with elements of state defense would be well attached in the Indonesian character if it's done through thorough understanding, empowering beliefs, and earnest commitment from every part of the society. That it enables the implementation of a proper principle of citizenship.

UPN "Veteran" Jakarta is a state defense university that has fulfilled the requirements in consideration of becoming a state university as stated by the Ministry of Culture and Education. Out of three considerations, the UPN "Veteran" Jakarta has fulfilled two of the considerations. Which is the consideration of historicity and special mission in which the UPN "Veteran" Jakarta could provide something novel that can't be provided by other state universities as the university based on state defense. The history of UPN "Veteran" Jakarta in the perspective of state character building has become a necessity in answering the challenges faced by the citizenship.

Leadership in general terms is the ability or the capability in an individual to influence others in order to achieve a certain goal. Leadership is the ability innate in a leader that constitutes traits such as: personality, capability, and willingness (Wahjosumidjo, 1987:11). Leadership is a sequence of activities by the leader that can't be separated from its position, style, and the behavior of said leader, as well as the interaction between the leader and its followers.

Basing on what have stated on the background above, the team will resume our research in exploring further on the urgency of the value of state defense in enacting leadership action within the faculty of UPN "Veteran" Jakarta.

\section{Literary Review}

\subsection{State Defense}

State defense as an idea is the will, attitudes, and the action of any citizens that is done widely and properly. Driven by the patriotism towards the country as told by the Pancasila and UUD 1945 (i.e., the constitution) in order to ensure the safety and well being of the states. The law stating the idea of state defense are written in the $27^{\text {th }}$ Law, verse 3 of the UUD 1945 which states that all citizens are given the rights and duty to join the state defense effort. As well as the $30^{\text {th }}$ law verse 1 of the UUD 1945 that states all citizens are given the rights and duty in the effort of defense and security of the states.

The core principles of state defense can be grouped into six categories: 1) patriotism; 2) citizenship; 3) loyalty to Pancasila as the state ideology; 4) willingness to sacrifice for the state; 5) in possession of basic state defense capability in terms of both mental and physical; 6) the spirit to realize a just and prosperous nation (cited from SE-12/SJ/2019 issued by the Ministry of Treasury). Patriotism is the realization of state defense in every individual citizen that is based on their devotion towards the state by conserving its culture, environment, and the states reputation. Citizenship can be realized through avoiding conflict between individual or differing groups. Pancasila as the state ideology must be practiced in every day lives as it was the uniting factor for the diversity in Indonesia. The basic state defense capability can be realized by keeping discipline, abiding the law, and preserving work ethics to each respected profession.

According to Udin S Winataputra (2010:1), the process of building a character for the nation should be focused on three bigger aspects: 1) to grow and strengthen state's identity' 2) to keep the unity of 
Indonesia; and 3) to shape a dignified and noble Indonesian citizen.

Undang-Undang Nomor 3 Tahun 2002 (Law No. 3 Year 2002) regarding the national defense explain that the effort in state defense is the attitude and action of every citizen that is motivated by their devotion towards the nation as based on Pancasila and UUD 1945. By that basis, state defense education and training for every citizen becomes a necessity that can't be compromised. State defense education are deemed relevant strategically important, aside from developing national defense it is also beneficial in improving the understanding and budding the value of patriotism. Therefore, it is by default that the citizenship that is based on a good understanding of statesmanship is to be developed for every citizen of Indonesia.

Citing Ales Suseno (2000) from the Indonesian State Defense Summit held in Jakarta on 31 August 1991, as the continuation of State Defense National Symposium, the "state defense declaration" has been addressed by several public figure. Which in summary states:

1. That state defense is a valuable trait for the nation that's absolutely necessary in every aspect of state affair to ensure the unity of Indonesia.

2. That state defense should be made well known by the public and actualized to realize the advanced, prosperous, and just society according to the UUD 1945.

3. That state defense is a national movement that is universal, populist, and regionalized in form of political education that encourages the consciousness towards a patriotic identity of each individual Indonesian through its action and attitude towards the state defense.

Improvement of the agreed values embedded by the nation, organization, society, which rooted from customs, beliefs, symbols, with certain characteristics can be differentiated from one another as the basis of any attitudes and responses towards what's occurring can be defined as the process of national character building. Character education according to Eric Digest are:

“...is an umbrella term used to describe many aspects of teaching and learning for personal development. Some areas under this umbrella are 'moral reasoning/cognitive development', 'social and emotional learning', 'moral education/virtue', 'life skills education', 'caring community', 'health education', 'violence prevention', 'conflict resolution/peer mediation', and 'ethic/moral philosophy...." (Character Education, Eric Digest)

State defense education has been reduced in its portion since the reform period. Beginning from Pendidikan Moral Pancasila (Pancasila Morale Education) and Pendidikan Kewiraan either through (boy) scouts or college regiments, several of these methods are erased or had its name slightly altered.

\subsection{Benefits of State Defense}

The benefits of state defense are as such: 1) encouraging discipline in time, activities, and any related management; 2) builds team works and solidarity among peers; 3) toughen mental and physical capabilities; 4) to encourages patriotism that is suitable to own abilities; 5) to train leadership in terms of self-leadership or group leadership; 6) to strengthen the belief in each individual; 7) to encourages devotion towards parents, the nation, and each individual religion; 8) to train one's agility in performing tasks; 9) to get rid of any negative traits such as laziness, apathy, lavishness, selfishness, and lack of discipline; 10) to shape a more preferable trait such as honesty, decisiveness, justness, and concern towards others. 


\subsection{State Defense Leadership}

Every citizen is a leader with their own responsibilities and differing degrees of leaderships. The degree of leadership will determine the problem-solving quality. This is where the importance of improving one's quality of leadership comes into play. By gradually improving the minds to better the quality of individual in facing various life problems, including one related to citizenship lives.

Leadership is the activity in influencing others through the method of communication in order to achieve a certain goal. It involves the act of coercing others through order, guidance, or any kind of actions that would move others to action, response, and enact positive changes. In a leadership, a dynamic form of power is needed to motivate, coordinate, and to organize the group to reach a certain objective.

The most important factor in leadership are: "attitude" and "integrity". Integrity implies the condition where there's congruence between actions and what's being said. Leadership covers the process of influencing and defining the goal of an organization. As well as motivating the behavior of followers to reach that said goal by affecting or improving its work ethics. Leadership becomes crucial for the leader to take the vital role as the motivator of the organization. The leader should also be the role model for the organization, to define the culture and to be the problem solver for the organization. A successful leader should have the integrity, along with moral and professionalism. Integrity relates with loyalty, honesty, while moral relates on determining what is right and wrong. A bad behavior such as cheating, fabricating, and grafting is the root of the problem. Contemporary leadership that is based on the state defense principle should possess these four types of traits: 1) technical competency which relates to the organization's main tasks; 2) management competency which constitutes the competency regarding management issues relating to the organization's tasks; 3) social competency which involves the ability to perform the necessary communication in carrying the organization's tasks; 4) intellectual competency which is the ability to think strategically with forward thinking vision, this competency covers the ability to define the mission and the strategy in order to achieve the goal of the organization. If any of the leaders and to-be-leaders has understood and comprehend that said four traits, they should automatically possess the national integrity and identity.

Leader's actualization can be in the form of ensuring justice, a stable condition, a more effective and efficient process, giving productive feedbacks, opening up work opportunities, utilization of resources and investments, ensuring equal payment distribution, as well as improving national unity and security.

The degree of leadership is the ability in solving a problem and can be measured from the scale of the problems that are handled.

\subsection{Research Method}

Research Strategy Planning by the UPNVJ: optimizing the role of (internal) communication strategy and giving recommendations in carrying out research regarding organizational communication especially in academic aspects. Researchers will focus in the urgency of state defense value in performing leadership role. The Urgency of State Defense in Enacting Leadership within the UPN "Veteran" Jakarta is a research aiming at giving input and recommendations for the university chair. In hopes of the chair would lead the university by prioritizing the state defense value.

This research will be using qualitative approach, where the core of the research is considered dynamic by nature, so the process was meant in order to understand the situation thoroughly and to produce a set of recommendations related to the urgency of state defense value. Descriptive method will also be used in this research as the problem-solving procedure, examined by illustrating the subject's situation or the research's objective (whether it be individual, institution, or society) in current times according to observable facts or how it is. (Nawawi, 2005:63) 


\section{Conclusion and Recommendation}

\subsection{Conclusion}

From the gathered respondent data, it is observed from several different aspects that:

a. Patriotism

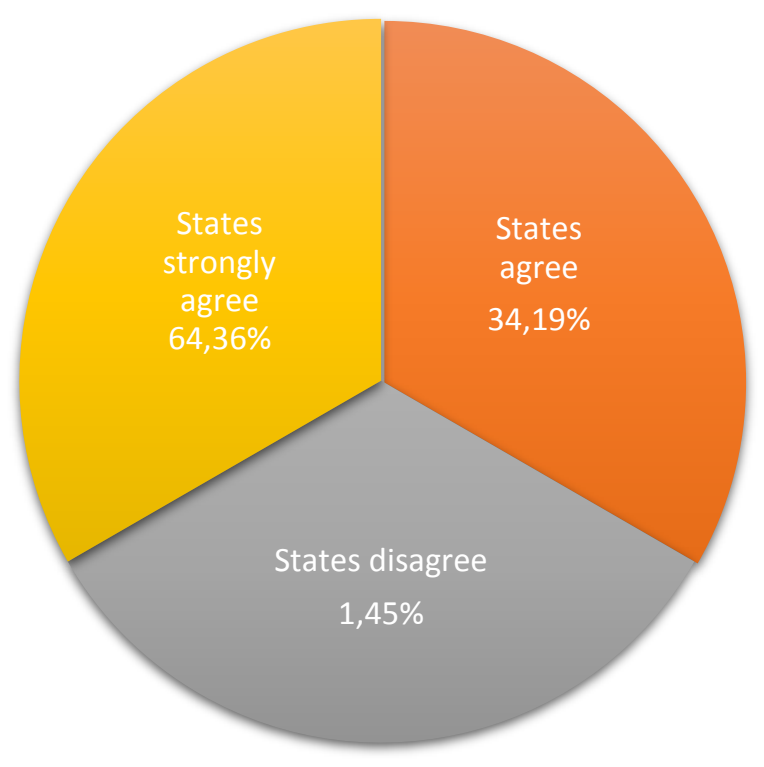

b. Citizenship

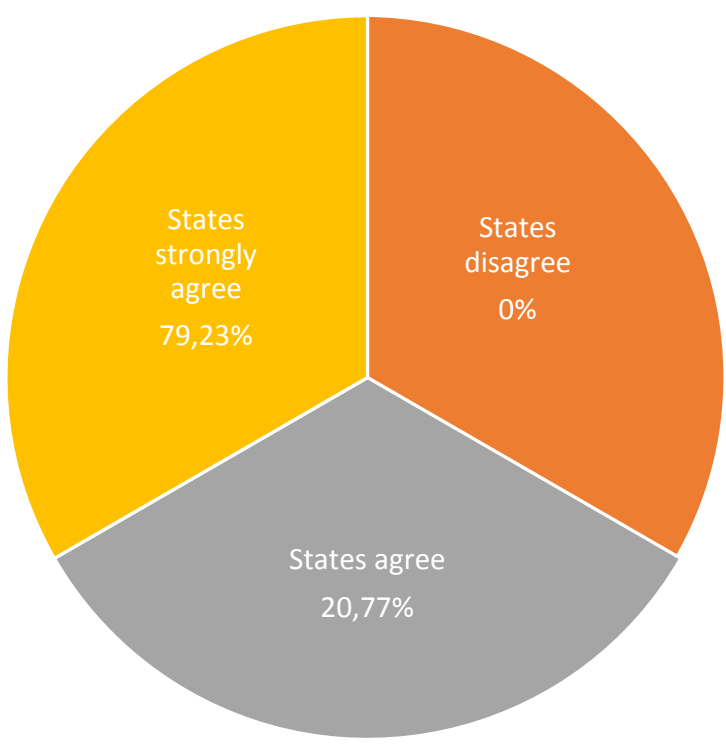




\section{c. Loyalty to Pancasila}

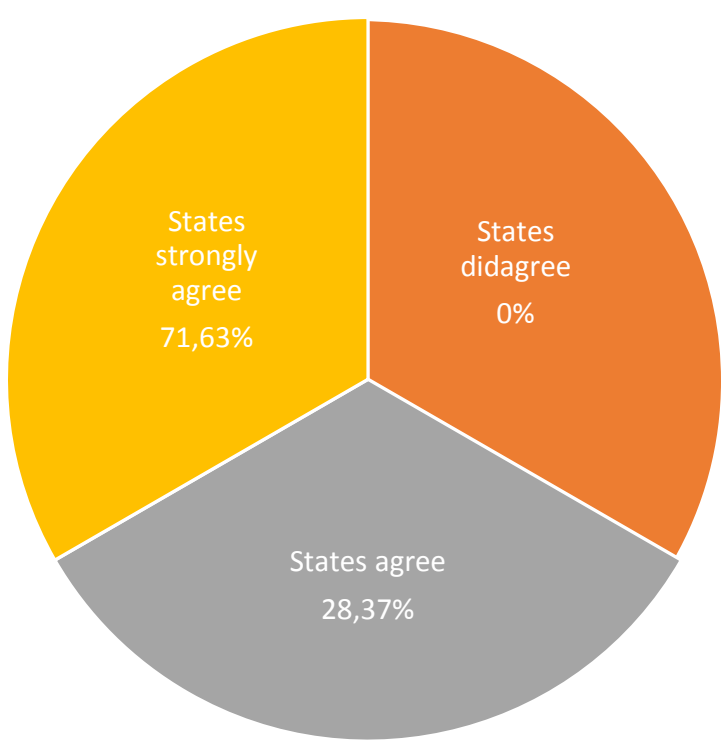

d. Willingness to Sacrifice for the Nation

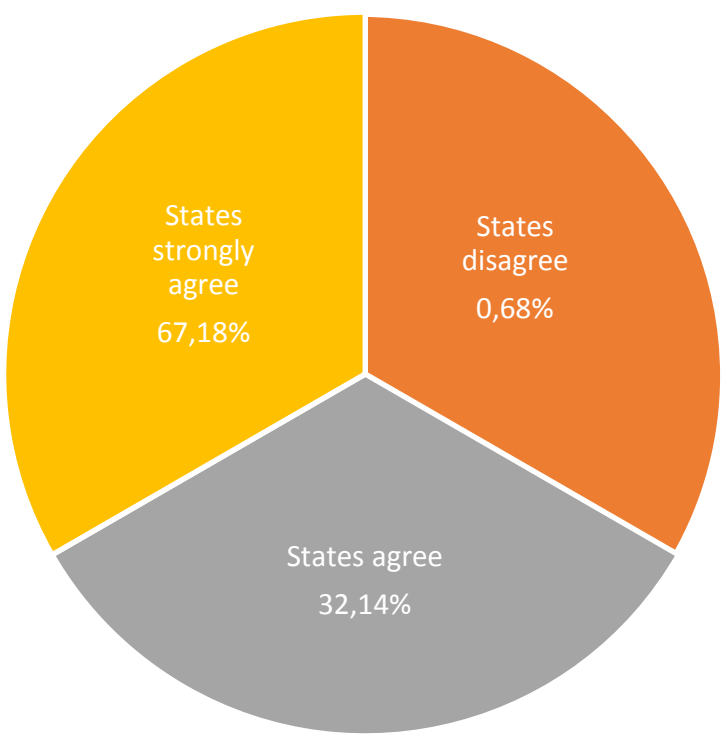


e. In Possession of Basic State Defense Value

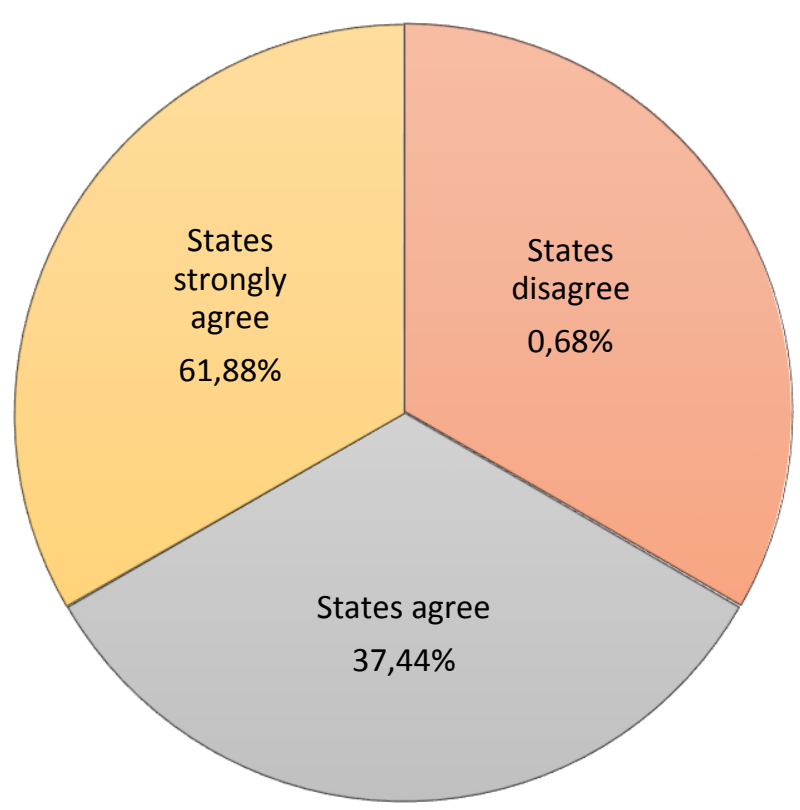

f. The Spirit to Realize a Prosperous and Just Nation

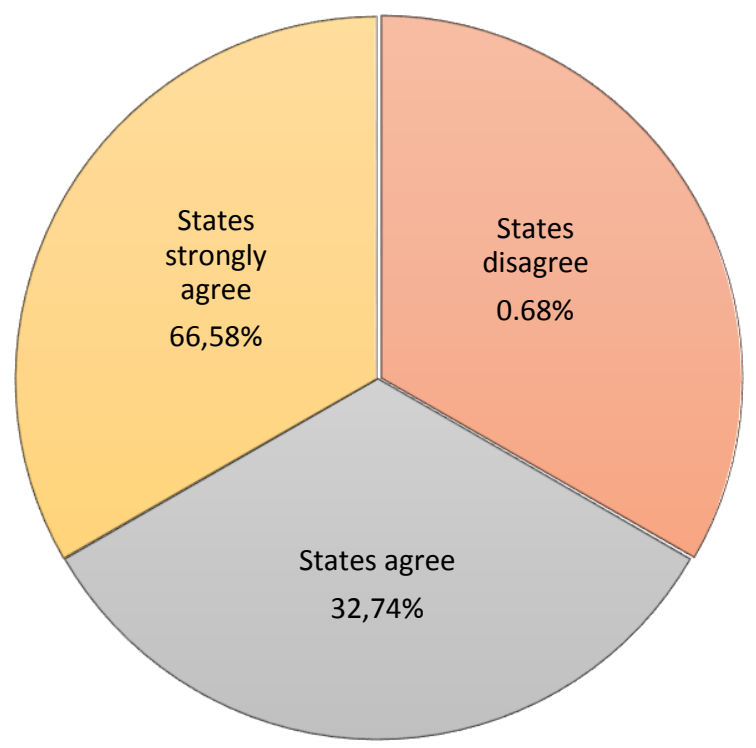


From the entire observed aspects, it can be concluded that in order to carry out leadership role and enacting state defense value, around $68,48 \%$ states strongly agree, $30,94 \%$ states agree, while $0,58 \%$ states strongly disagree and $0 \%$ states not knowing.

It can be said that in terms of the urgency of state defense value in carrying out leadership role, majority of respondents states strongly agree.

\subsection{Recommendation}

1. A leader in carrying out the leadership role should refer to the state defense value.

2. The urgency of state defense is a must for a leader.

3. It is advisable to become a trustworthy leader in order to avoid misappropriation.

\section{Bibliography}

Irawatie Aniek, Iswahyuni, Marina Ery Setyawati, 2017, Representasi Mahasiswa Tentang "Kampus Bela Negara" Universitas Pembangunan Nasional "Veteran" Jakarta, Penelitian Produk Terapan, UPN "Veteran" Jakarta.

Kartini Kartono 2010, Pemimpin dan Kepemimpinan, PT Raja Grafindo Persada, Jakarta

Kwartolo, Yuli, 2010. “Teknologi Informasi dan Komunikasi dalam Proses Pembelajaran". Jurnal Pendidikan Penabur. No.14/Tahun ke-9/Juni.

Leslie Baxter dalam Arneson, P, 2007. Edisi 2. Perspectives on Philosophy of Communication. Indiana: Purdue University Press.

Lewis, Kirsten, 1996. “Character Education Manifesto”, News, Boston University. Littlejohn, Stephen W dan Foss Karen A, 2009. Teori Komunikasi, (Translation), Jakarta, Salemba Humanika.

Malik A Fadjar, 2013. Kemana Arah Pendidikan di Indonesia Pokok-pokok bahasan untuk "Round Table Discussion" presented on Forum Round Table Discussion "Refleksi Pendidikan Akhir Tahun 2013" Held by FKIP Universitas Muhammadiyah Malang (UMM) Malang, Jawa Timur: Aula BAU, 12 December.

Muhammad Busro, 2018. Teori-teori Manajemen Sumber Daya Manusia, Prenada Media Group, Jakarta

Ratnamegawati, 2007. Pendidikan Karakter, Solusi Tepat Untuk Membangun Bangsa. Jakarta, Viscom Pratama.

Rianti Nugroho, 2008, Pendidikan Indonesia: Harapan, Visi,dan Strategi, Jogjakarta: Pustaka Pelajar.

Sondang P Siagian 2010. Teori dan Praktek Kepemimpinan, Rineka Cipta, Jakarta.

Suyanto. 2013. Makna dan Tantangan Pendidikan Nasional dalam Menghadapi Globalisasi Makalah presented on Forum Round Table Discussion "Refleksi Pendidikan Akhir Tahun 2013" Held by FKIP Universitas Muhammadiyah Malang (UMM) Malang, Jawa Timur: Aula BAU, 12 December. 
Udin. S. Winataputra, 2010. "Peran Pendidikan Ilmu Pengetahuan Sosial (IPS) dalam Konteks Pembangunan Karakter Bangsa", Makalah, presented on Seminar Internasional held by HISPISI dan UNM di UNM Makasar, 13-14 July.

Udin. S. Winataputra, 2010. "Peran Pendidikan Ilmu Pengetahuan Sosial (IPS) dalam Konteks Pembangunan Karakter Bangsa", Makalah, presented on Seminar Internasional held by HISPISI and UNM at UNM Makasar, 13-14 July.

Zainal Abidin, Djoko Poernomo, Endang Iryandi, Lukman arif, 2014, Buku Ajar Bela Negara, Universitas Pembangunan Nasional "Veteran" Jawa Timur.

\section{Copyrights}

Copyright for this article is retained by the author(s), with first publication rights granted to the journal.

This is an open-access article distributed under the terms and conditions of the Creative Commons Attribution license (http://creativecommons.org/licenses/by/4.0/). 